\title{
Strength effect of alccofine on ordinary and standard grade concrete mixes
}

\author{
BLN Sai Srinath ${ }^{1}$, Chandan Kumar Patnaikuni ${ }^{2}$, Santhosh Kumar B. ${ }^{3 *}$, Balaji K.V.G.D ${ }^{4}$ and Kode \\ Venkata Ramesh ${ }^{5}$ \\ Research Scholar, Department of Civil Engineering, G.I.T.A.M. Institute of Technology, G.I.T.A.M. University, \\ Visakhapatnam 530045, Andhra Pradesh, India ${ }^{1}$ \\ Assistant Professor, Department of Civil Engineering, G.I.T.A.M. Institute of Technology, G.I.T.A.M. University, \\ Visakhapatnam 530045, Andhra Pradesh, India ${ }^{2}$ \\ Deputy Executive Engineer, Water Resources Department, Vizianagaram.535001, Andhra Pradesh, India ${ }^{3}$ \\ Distinguished Professor, Department of Civil Engineering, G.I.T.A.M. Institute of Technology, G.I.T.A.M. \\ University, Visakhapatnam 530045, Andhra Pradesh, India ${ }^{4}$ \\ Professor, Department of Civil Engineering, G.I.T.A.M. Institute of Technology, G.I.T.A.M. University, \\ Visakhapatnam 530045, Andhra Pradesh, India ${ }^{5}$
}

Received: 30-August-2021; Revised: 20-January-2022; Accepted: 22-January-2022

(C)2022 BLN Sai Srinath et al. This is an open access article distributed under the Creative Commons Attribution (CC BY) License, which permits unrestricted use, distribution, and reproduction in any medium, provided the original work is properly cited.

\begin{abstract}
Concrete is an indispensable construction material used worldwide. It primarily consists of the binder phase and aggregate phase. In the binder phase, cement replacement with silica fumes, fly-ash and ground granulated blast furnace slag (GGBS) is recommended in design mix guidelines (IS 10262-2019). However, ultra-fine material like Alccofine was not recommended as supplementary cementitious material. This paper addresses the suitability of this admixture for concrete of various grades i.e. M20, M30 and M40 grade mixes. The relevant hardened concrete strength for 5\%, $10 \%$, $15 \%$, and $20 \%$ cement replacement with Alccofine was tested. All the design mixes established the acceptance criteria of test results. However, the highest test results were obtained for $15 \%$ replacement of Alccofine for all the mixes. Surprisingly the 28 days strength of M20 grade concrete was achieved even at seven days curing test results. In summary, the Alccofine material can reduce the consumption of cement and $\mathrm{CO}_{2}$ emissions in the atmosphere.
\end{abstract}

\section{Keywords}

IS 10262, Design mix guidelines, Admixture, Alccofine, Hardened concrete, Flexural strength, Compressive strength, Tensile strength.

\section{Introduction}

Concrete, which is an indispensable construction material that occupies the second-largest material after drinking water for humankind. It has an annual consumption of 2.4 tons per person of the world population, which is more consumption when compared to steel, timber, drinking water, and other materials [1]. Similarly, cement has an annual consumption of 0.4 tons per person of the world population. Advancement in research and development has significantly changed from the 19th century to the present scenario. These changes occurred in the design mix methodologies with part replacement of cementitious materials and other than natural aggregates in the aggregate phases in the concrete [2].

*Author for correspondence

47
These changes have been very significant for sustainable development growth to reduce global warming. This global warming is primarily caused by the carbon-di-oxide $\left(\mathrm{CO}_{2}\right)$ gases released by the industries. In the case of the cement industry, for manufacturing 1 ton of cement, releases 1 ton of $\mathrm{CO}_{2}$ approximately. Hence, even if we reduce a fraction percentage of cement in concrete, much $\mathrm{CO}_{2}$ is lessened [3].

In concrete, cement is used as a binder of the aggregates, which forms the composite material [4]. While manufacturing the cement, $\mathrm{CO}_{2}$ is emitted into the atmosphere. It consists of $9 \% \mathrm{CO}_{2}$ emissions attributed to Portland cement production [5]. The cement industry also releases around 7\% of global greenhouse gases (GHGs). Compared to other greenhouse gases, $\mathrm{CO}_{2}$ represents a more significant 
portion of the energy sector's GHGs. Hence, there is an imperative need in the construction industry to focus on sustainable materials to cater to the exponential growth of the population [6]. Even though concrete has the least embodied energy compared to other engineered materials, its impact on the environment is very high. As a result, $\mathrm{CO}_{2}$ levels are rising substantially. Hence, the construction industry is responsible for a more considerable amount of release of $\mathrm{CO}_{2}$.

In concrete, pozzolanic reactions can reduce the pore space in the interfacial transition zones (I.T.Z.) [7]. Consequently, concrete structures exposed to aggressive environmental conditions are built with newly developed supplementary cementitious materials (S.C.M.) or pozzolana materials [8]. The use of S.C.M.s in concrete manufacturing as a partial replacement for cement is one of the most significant technical developments in the industry. Concrete used a more incredible amount of S.C.M.s as binary, ternary, or quaternary combinations. It is possible to utilize S.C.M.s for both financial and environmental reasons without compromising strength and durable parameters.

Alccofine, a novel superfine slag-based material, has been developed recently. It exhibited higher strength and durability properties than other S.C.M.s used in the construction industry [9]. It has remarkable attributes in the overall potency in fresh and hardened concrete properties. The more refined materials produced from the byproducts of steel or iron industries are known as ultrafine slag materials. Alccofine is one such material that contains up to 6micron individual particle size. Silicon dioxide $\left(\mathrm{SiO}_{2}\right)$ is a significant constituent contributing to the strength parameters [10]. Even high-performance concrete is more durable with the addition of Alccofine and other such materials [11]. Due to the pozzolanic action of cement, the addition of Ground granulated blast furnace slag (GGBS), and their micro filler effect, the cement paste matrix demonstrated a less pore structure [12]. It was found that concrete with 88.3\% Alccofine and $16.3 \%$ FA was more substantial in compressive and flexural tests [13]. Past research demonstrated that the $3-18 \%$ of Alccofine as a cement replacement is a higher strength parameter in the relevant concrete grades. Further, $13 \%$ Alccofine replacement produced a higher cube strength than the cylinder [14]. Concrete with Alccofine and other Pozzolanic material viz., FA and GGBS. can be used as partially replaced by cement [15]. Alccofine has created enhanced self-compacting concrete properties [16].

Even though the Alccofine cannot contain the binding property, as but consequence of the combination of cement, it has a capacity of excellent bonding property. This property established a significant increment in compressive strength [17].

It is economical to use byproduct waste materials in the construction industry to achieve comparable performance with reducing costs. This alternative material can reduce the need for Portland cement to produce a unit volume of concrete and reduce the enormous deflationary effects of GHG emissions.

By and Large, Alccofine performs more effective SCM than many of the mineral admixtures currently used in India. Alccofine 1203 has more strength gain in the early ages than silica fume. The cement and Alccofine materials are shown in Figure 1 and Figure 2.

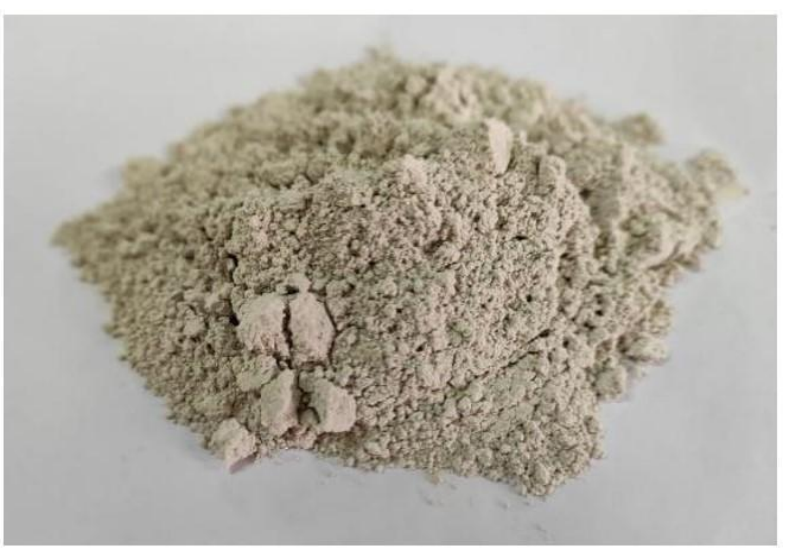

Figure 2 Alccofine
Figure 1 Cement

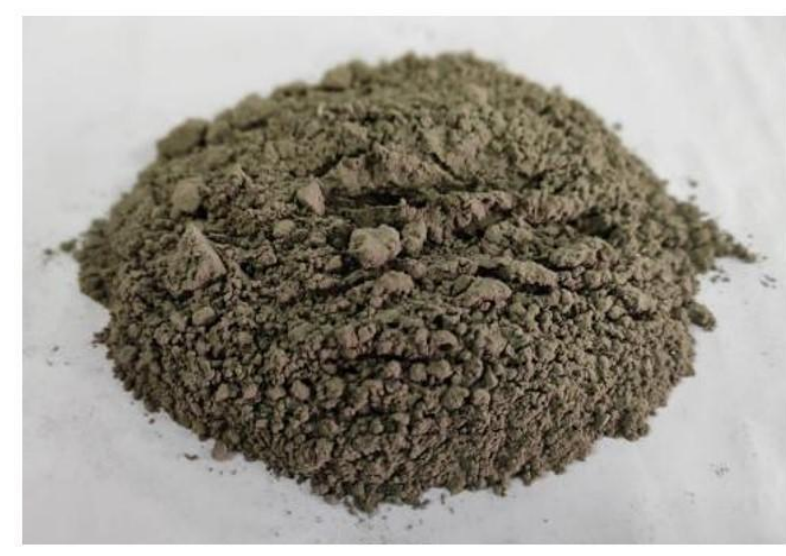

48 


\section{Literature review}

Gayathri et al. [18] had investigated the mechanical strength characteristics and durability strength parameters of self-consolidating concrete with $30 \%$ GGBS and 0 to $20 \%$ as a partial substitute for Alccofine. Combining both materials enhanced the mechanical properties at $10 \%$ Alccofine replacement only. The combination of Alccofine and GGBS was investigated in nine different ways to compare the strength and durability parameters. The remarkable strength gains were observed for the variety of $10 \%$ Alccofine and 30\% GGBS replacement in the designed mix proportions.

Sanjeev et al. [19] probed the M40 grade lightweight concrete properties by replacing coarse aggregate with a coconut shell, and Alccofine replaced cement at $6 \%, 8 \%, 10 \%$, and $12 \%$. Various tests were conducted to find the wet density, dry density, and compressive strength. The comparative results show that $30 \%$ coconut shell replacing coarse aggregate and $8 \%$ Alccofine replacing cement established the best results without compromising the strength loss.

Reddy and Meena [20] substituted Alccofine, FA, and GGBS partially into cement in M30 grade concrete. The Alccofine was replaced at 5\%, 10\%, $15 \%, 20 \%, 25 \%$, and $30 \%$ of cement. Similarly, Flyash and G.G.B.S. were introduced with $0-40 \%$ cement. The 10\% Alccofine along with 25\% Flyash is found appropriate combinations. However, favorable results were not noticed from the other combination of A.L. and G.G.B.S.

Chandar et al. [21] have experimentally analyzed the influence of Alccofine on debris/recycled aggregate on mechanical strength properties of reinforced concrete beams. Alccofine partially replaced cement at $5 \%, 10 \%, 15 \%, 20 \%$, and $25 \%$. Similarly, recycled aggregates replaced the natural aggregates by $0 \%$, $30 \%, 50 \%$, and $100 \%$. The results indicated the compressive strength for both $30 \%$ and $50 \%$ of recycled aggregate together with $20 \%$ Alccofine was achieved equal to normal concrete strengths. The maximum splitting tensile values of concrete made of recycled aggregate was obtained at $20 \%$ Alccofine. Also at 30\% recycled aggregate along with $20 \%$ Alccofine, the maximum flexural strength was obtained.

Asad et al. [22] have examined the inclusion of Perlite along with Alccofine as a fractional substitution in M50 grade concrete. The mechanical strength with of the concrete with varying levels of
Alccofine i.e. $0 \%, 5 \%, 10 \%, 15 \%, 20 \%, 25 \%$ were added and along with Perlite varying at $0 \%, 1 \%, 3 \%$ and 5\% were inspected at 7 days and as well as 28 days curing period. Concrete strength increased compared to nominal mix concrete up to $15 \%$ for Alccofine and 5\% for Perlite.

Kaviya et al. [23] experimentally observed the exhibition of Alccofine concrete by partially adding cement at 5\%, 10\%, 15\% for ascertaining both compressive and cylindrical split tensile strengths for 7 days and 28 days. The maximum compressive strength was attained at $15 \%$ Alccofine.

Ghising and Kumar [24] experimentally observed the effect of M35 grade concrete mix properties for different curing regime with $0 \%, 5 \%, 10 \%, 15 \%$ \& $20 \%$ Alccofine. The results found that the at $15 \%$ replacement of Alccofine produced the maximum compressive strength, but $10 \%$ replacement produced the highest split tensile strength.

Rajesh et al. [25] conducted the tests to explore the high strength concrete (HSC) M60 grade concrete properties with Alccofine at 5\%, 10\%, 15\%, and 20\% replacement. It is proposed that at $10 \%$ of Alccofine asserted the highest strengths. When the Alccofine replaced the cement beyond $10 \%$, it acted as a filler material but yields good workability to the concrete.

Narasimha and Ahmed [26] experimentally analyzed the mechanical strength as well as the durability aspects of M30 grade concrete with and without and green Alccofine substitution. Alccofine was added at 10,20 , and $30 \%$ by weight of cement content. The concrete mix proportion was designed for a water/cement ratio of 0.45 . It was concluded that up to $20 \%$ of Alccofine, the three standard strength properties were increasing.

Mathur and Mathur [27] have inspected the M20 grade concrete at $1 \%, 2 \%, 3 \%, 4 \%, 5 \%, 10 \%$, and $15 \%, 20 \%$ Alccofine substitution. The compressive strength for the ages of 3 days, 7days, and 28 days is determined that $10 \%$ of partial replacement of cement with the ultrafine slag i.e. Alccofine in M20 grade concrete witnessed a higher compressive strength.

Nainwal et al. [28] addressed the effectiveness of M20 grade concrete with Alccofine as S.C.M. After adding Alccofine equal to $3 \%$ of total cement; the compressive strength was increased. The result showed that the concrete with Alccofine showed a better result than the nominal concrete. The 
compressive strength with $3 \%$ Alccofine increased from $19.8 \mathrm{~N} / \mathrm{mm}^{2}$ to $25.8 \mathrm{~N} / \mathrm{mm}^{2}$.

Gupta [29] experimented the effects of partial cement substitution with ultra-fine slag (Alccofine) for the mechanical strength variations of concrete of grade M50 grade. Concrete containing Alccofine was found to have higher fresh concrete properties. $13 \%$ of Alccofine was found to enhance concrete's properties. The lowest difference strength parameter was seen after $10 \%$ replacement of Alccofine with conventional concrete.

Suganya and Maheshwari [30] have replaced cement with Alccofine for $0 \%, 5 \%, 10 \%, 15 \%, 20 \%$, and $25 \%$ of partial replacement and fine aggregate was replaced with manufactured sand to evaluated the 7 , 14, and 28 days compressive strengths. It was found that the optimum level of Alccofine was found at $15 \%$. The highest compressive strength was achieved at $100 \%$ replacing manufactured sand and $15 \%$ replacing Alccofine in the concrete.

Nishanth and Patil [31] as part of their study, examined different SCGC mix designs based on slag, flyash, and ultrafine slag i.e. Alccofine, and compared their workability as well as strength characteristics. Across all mixes, binder contents were varied between $400-450 \mathrm{~kg} / \mathrm{m}^{3}$. For each mix, the $\mathrm{NaOH}$ concentration was varied between 10,12 , and 14M. The slag based GGBS composed of $60 \%$ and low calcium fly ash composed of $35 \%$ were used for each mix to make SCGC. In accordance with the recommendations by EFNARC, SCGC's workability was observed by performing the J-ring test, L-Box test, Slump test, V-funnel test, and T50 slump test. With $450 \mathrm{~kg} / \mathrm{m}^{3}$ binder content and 10 Molar $\mathrm{NaOH}$ solution, SCGC mix results in a maximum flow rate of $715 \mathrm{~mm}$. As the molarity of the $\mathrm{NaOH}$ solution increased, the flow decreased. In a trial containing 16 $\mathrm{M} \mathrm{NaOH}, 100 \%$ GGBS, and $500 \mathrm{~kg} / \mathrm{m}^{3}$ binder content, the least flow was measured at $600 \mathrm{~mm}$.

Patil [32] described that the substantial delay due to hand compaction or vibrating of concrete during casting is one of the major reasons for the change in concrete properties. Considering this issue in this study, research was conducted on the development of an SCGC with various industrial by-products such as FA, GGBS, and Alccofine in varying binder percentages of $80: 10: 10,65: 20: 15$. This ratio of 65:20:15 performed well for mechanical strength and durability. Due to environmental issues and global warming, research has to be conducted on such industrial waste products to find ways to repurpose them in environmental-friendly projects.

Harish et al. [33] developed a new material in order to overcome the problems associated with concrete strength. Due to the advent of large construction equipment and plants throughout the world, as well as the enlargement of the use of construction materials, the use of additive mineral by-product admixtures to improve the quality of concrete has grown. Developed through experiments and research is cement-based concrete that has special performance with regards to strength, durability, and adaptability called "High-Performance Concrete (HPC)". With the replacement of cement by Alccofine, strength was observed to increase by $10 \%$. By replacing cement with Alccofine, both normal and high strength concrete experiences an early development of strength.

\subsection{Significance of the research}

From the above Literature, it was found that various percentage replacements of Alccofine from $3 \%$ to 25 $\%$ attributed the strength parameters of different concrete mixes from the standard grade concrete to High strength grade mix proportions. Along with the other additives. The Indian standard concrete design mix guidelines (I.S. 10262:2019) recently recommended the partial substitution of cement with GGBS and FA and silica fume materials only. Secondly, but not advocating the usage of the ultrafiner materials like Alccofine. Hence the design mix guidelines were adopted as a trail mix for M20, M30 and M40 concrete grades are proportioned with 5\%, $10 \%, 15 \%$, and $20 \%$ replacement of cement with Alccofine to ascertain the strength parameters replaced with cement to find the standard strength properties. The design method is shown in the flow diagram.

\section{Methodology}

The Alccofine based concrete mix proportions were computed as shown in Figure 3 with the recommendations of Indian Standard code 102622019 version [34].

\subsection{Cement}

The test properties of Grade 53 Ordinary Portland Cement are shown in Table 1.

3.1.1Fine aggregates

The Natural sand obtained from the nearby river is tested for the physical properties according to I.S. 2386:1963(Reaffirmed 2002) [35]. The results are 
shown in Table 2 with fineness modulus of 2.77, which signifies the medium grade sand.

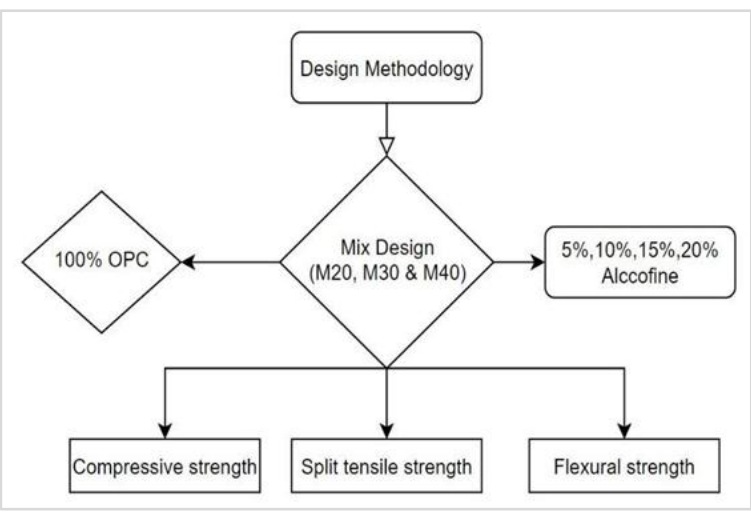

Figure 3 Methodology

Table 1 Physical properties of cement

\begin{tabular}{llll}
\hline S. No. & Features & Values & Units \\
\hline 1 & Fineness & 310 & $\mathrm{~m}^{2} / \mathrm{kg}$ \\
\hline 2 & Soundness & 1.2 & $\mathrm{~mm}$ \\
\hline 3 & $\begin{array}{l}\text { Specific gravity of } \\
\text { cement }\end{array}$ & 3.15 & - \\
\hline 4 & Standard consistency & 33 & $\%$ \\
\hline 5 & Initial setting time & 33 & minutes \\
\hline 6 & Final setting time & 600 & minutes \\
\hline
\end{tabular}

Table 2 Physical properties of fine aggregate

\begin{tabular}{llll}
\hline S.No. & Properties & Values & Units \\
\hline 1 & Specific gravity & 2.65 & - \\
\hline 2 & Fineness modulus & 2.77 & - \\
\hline 3 & Zone & II & - \\
\hline 4 & Bulk density & 1652 & $\mathrm{Kg} /$ cum \\
\hline
\end{tabular}

\subsubsection{Coarse aggregate}

The coarse aggregate used was machine crushed hard granite $20 \mathrm{~mm}$ (MSA). The tested properties as per I.S. 2386:1963 are shown in Table 3.

Table 3 Physical properties of coarse aggregate

\begin{tabular}{llll}
\hline S. No. & characteristics & Values & Units \\
\hline 1 & Specific gravity & 2.85 & - \\
\hline 2 & Bulk density & 1822 & $\mathrm{Kg} / \mathrm{m}^{3}$ \\
\hline 3 & Fineness modulus & 7.1 & - \\
\hline 4 & Type & Angular & - \\
\hline
\end{tabular}

\subsubsection{Alccofine}

Alccofine is an ultra-fine slag that is sourced from Ambuja Cement Pvt. Ltd and shown in Figure 2. Table 4 and Table 5 show the properties of Alccofine. The chemical composition of Cement and Alccofine are depicted in the Table 5.
Table 4 Physical properties of Alccofine

\begin{tabular}{llll}
\hline S. No. & Characteristics & $\begin{array}{l}\text { Character/ } \\
\text { magnitude }\end{array}$ & Units \\
\hline 1 & Pattern & powder & - \\
\hline 2 & Odour & odorless & - \\
\hline 3 & Colour & Grey & - \\
\hline 4 & S.G. & 2.86 & - \\
\hline 5 & Fineness & 1200 & $\mathrm{~m}^{2} / \mathrm{kg}$ \\
\hline 6 & Density & 2.74 & - \\
\hline 7 & Bulk density & 700 & $\mathrm{Kg} / \mathrm{m}^{3}$ \\
\hline
\end{tabular}

Table 5 Chemical composition of cement and Alccofine

\begin{tabular}{lllll}
\hline S. No. & Properties & Cement & Alccofine & Units \\
\hline 1 & $\mathrm{CaO}$ & 64.5 & 34.4 & $\%$ \\
\hline 2 & $\mathrm{SiO}_{2}$ & 23.6 & 34.7 & $\%$ \\
\hline 3 & $\mathrm{Al}_{2} \mathrm{O}_{3}$ & 6.5 & 22.0 & $\%$ \\
\hline 4 & $\mathrm{Fe}_{2} \mathrm{O}_{3}$ & 3.8 & 1.18 & $\%$ \\
\hline 5 & $\mathrm{MgO}$ & 2.2 & 6.1 & $\%$ \\
\hline 6 & $\mathrm{SO}_{3}$ & 3.5 & 1.2 & $\%$ \\
\hline
\end{tabular}

3.1.4Superplasticizer (S.P.)

Super Plasticizers are used to increase the concrete rheology characteristics. Fosroc Conplast SP430 is one of such admixtures which is adapted in this research. The dosage quantity of the superplasticizer is calculated with respect to mix design. According to the manufacturer, the superplasticizer provided in the research work has properties which are shown in Table 6.

Table 6 Properties of superplasticizer

\begin{tabular}{lll}
\hline S. No. & Property & Character/Limits \\
\hline 1 & Colour & Brown viscous liquid \\
\hline 2 & Specific gravity & 1.20 \\
\hline 3 & Air entrainment & Less than $2 \%$ \\
\hline 4 & Chloride content & - \\
\hline
\end{tabular}

\subsubsection{Water}

Potable water from the University Laboratory is used for casting and curing and its $\mathrm{pH}$ value is 6.5.

\subsection{Mix proportions}

IS 10262-2019 guidelines have been adopted to design M20, M30, and M40 grade concretes mix proportions. Alccofine replaces the cement at 5\%, $10 \%, 15 \%$, and $20 \%$ weight. The mix proportions for the materials are shown in Table 7, Table 8, and Table 9. After 28 days curing period, the general hardened concrete strength properties have been examined in the lab to find the suitability of the mineral admixture. 
BLN Sai Srinath et al.

Table 7 Mix proportions of M20 grade concrete/cum

\begin{tabular}{llllll}
\hline & $0 \%$ & $5 \%$ & $10 \%$ & $15 \%$ & $20 \%$ \\
\hline Cement & 345 & 344 & 326 & 308 & 290 \\
\hline Alccofine & 0.0 & 18.16 & 36.31 & 54.47 & 72.62 \\
\hline Water & 148.0 & 152. & 152.0 & 152.0 & 152.00 \\
\hline F.A. & 750.0 & 652.2 & 652.2 & 652.2 & 652.27 \\
\hline C.A. & 1170. & 1322. & 1322. & 13223 & 1322.3 \\
\hline SP & 3.45 & 3.63 & 3.63 & 3.63 & 3.63 \\
\hline
\end{tabular}

Table 8 Mix proportions of M30 grade concrete/cum

\begin{tabular}{llllll}
\hline & $0 \%$ & $5 \%$ & $10 \%$ & $15 \%$ & $20 \%$ \\
\hline Cement & 356. & 353 & 334 & 316. & 297. \\
\hline Alccofine & 0.00 & 18.60 & 37.20 & 55.80 & 74.40 \\
\hline Water & 148.0 & 152.0 & 152.0 & 152.0 & 152.0 \\
\hline F.A. & 759.0 & 646.0 & 646.6 & 646.6 & 646.6 \\
\hline C.A. & 1155 & 1322 & 1322 & 1322 & 1322 \\
\hline SP & 3.60 & 3.70 & 3.70 & 3.70 & 3.70 \\
\hline
\end{tabular}

Table 9 Mix proportions of M40 grade concrete /cum

\begin{tabular}{|c|c|c|c|c|c|}
\hline & $0 \%$ & $5 \%$ & $10 \%$ & $15 \%$ & $20 \%$ \\
\hline Cement & 367.0 & 399.0 & 378.0 & 357.0 & 336.0 \\
\hline Alccofine & 0.00 & 21.0 & 42.0 & 63.0 & 84.0 \\
\hline Water & 148.0 & 152.0 & 152.0 & 152.0 & 152.0 \\
\hline F.A. & 767.0 & 646.6 & 646.6 & 616.0 & 646.6 \\
\hline C.A. & 1140 & 1322 & 1322 & 1308. & 1322 \\
\hline SP & 3.7 & 4.2 & 34.2 & 4.2 & 3.4 .2 \\
\hline
\end{tabular}

\subsection{Casting and curing of test specimens}

3.3.1Compressive strength

The fresh concrete properties, including slump values, have been ascertained for the desired workability of the concrete. The digital compressive testing machine (CTM) shown in Figure 4 was used for compression testing at 7 days and 28 days.

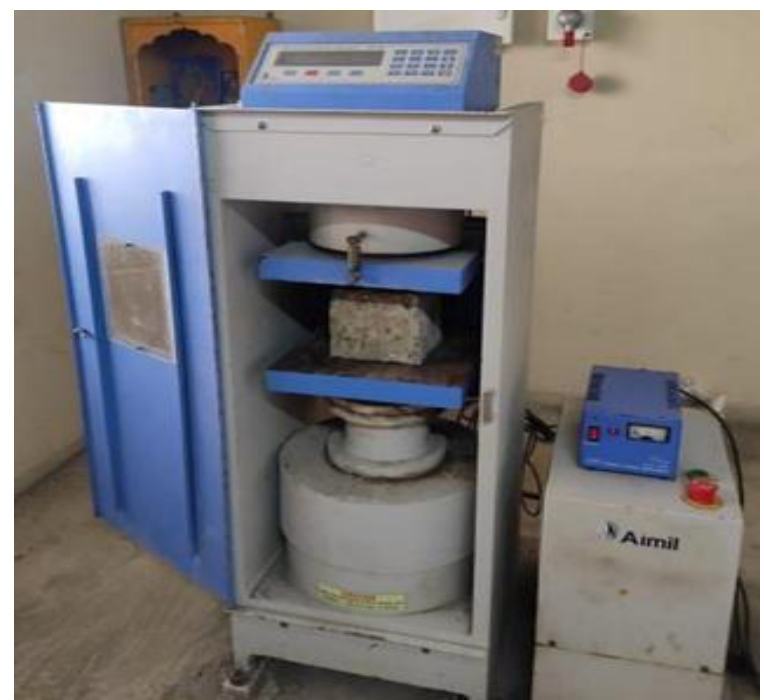

Figure 4 Compression testing machine (CTM)

\subsubsection{Split tensile strength}

The splitting tensile strength was performed on $150 \times 300 \mathrm{~mm}$ cylinder specimens. The tests were conducted after 28 days of water curing. Figure 5 shows the broken cylinder pieces in the machine.

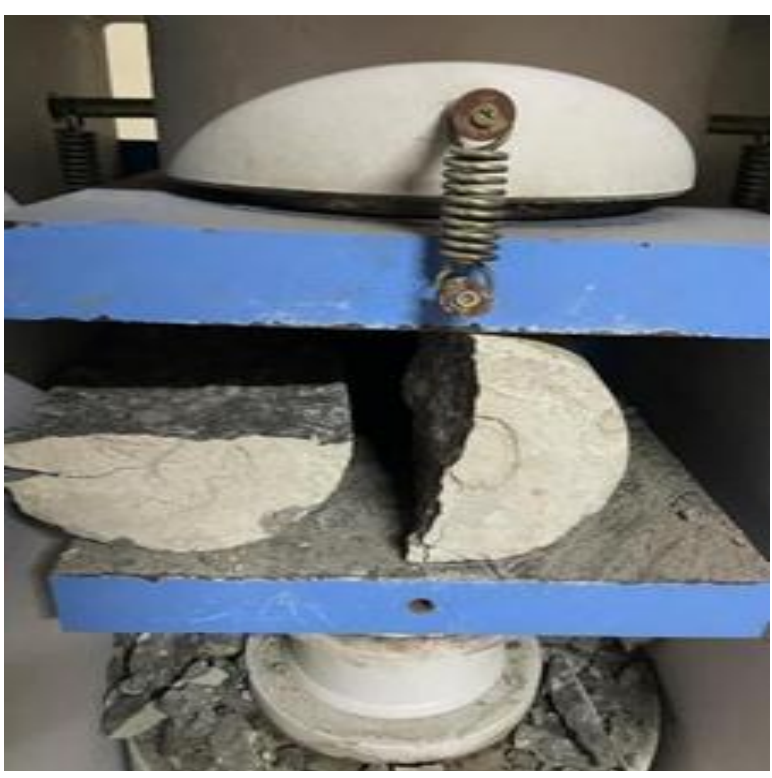

Figure 5 Split tensile strength testing 


\subsubsection{Flexural strength}

Prisms of size $100 \times 100 \times 500 \mathrm{~mm}$ are tested for flexural strength after 28 days of the curing period. The UTM machine is shown in Figure 6.

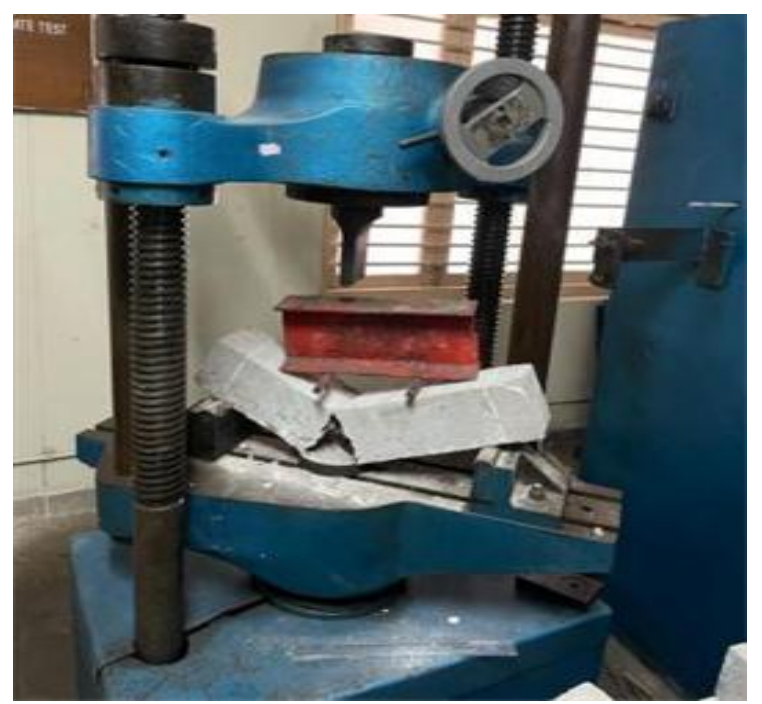

Figure 6 Flexural tensile strength testing

\section{Results}

With the due procedure adopted for other supplementary cementing materials in the concrete mix proportions, a similar approach is adopted for mix design of M 20, M 30, and M 40 grades for the 5 to $20 \%$ replacement of Alccofine with cement. The basic hardened strength properties were tested after 28 days of normal water curing. The compressive strength variations are shown in the Figure 7 to Figure 9. Similarly, the split tensile strength variations are shown from Figure 10 to Figure 12. Finally, the changes in flexural strength are shown in Figure 13 to Figure 15. The accepted limits of the strengths are also shown in the respective figure for ascertaining the acceptability criteria in all the results.

Three design mixes comprising M20 grade concrete as ordinary concrete mix and M30 and M40 grade as standard concrete mixes have been proportioned with IS 10262-2019 design guidelines with the acceptable limits of cement content and the water-cement ratios as well as water binder ratios. The proportion mixes are worked out for the max w/c for M20, M30 and M40 grade concrete is $0.46,0.43$, and 0.40 , respectively. Similarly, the w/b ratio for M20, M30 and M40 are $0.41,0.40$, and 0.36 respectively.

\subsection{Compressive strength}

Generally, the acceptance of any design mix is found by the 28-day cube compressive strength of the concrete in the laboratory. However, the seven days compressive strengths were also tested for ascertaining the rate of strength attained during the first seven days. The 7 days compressive strength of M20 grade concrete varies from $18.37 \mathrm{~N} / \mathrm{mm} 2$ to 26.87 Mpa up to $15 \%$ replacement of Alccofine, but a little decreasing trend after $20 \%$ replacement. Similarly, the 28days compressive strength of M20 grade concrete is varied from $28.30 \mathrm{~N} / \mathrm{mm} 2$ to 30.10 Mpa up to $15 \%$ replacement of Alccofine, but a little decreasing trend after $20 \%$ replacement. All the variations are shown in the Figures 7 to 9. Similarly, the seven-day compressive strength of M30 grade concrete varies from $24.07 \mathrm{~N} / \mathrm{mm}^{2}$ to $33.57 \mathrm{Mpa}$ up to $15 \%$ replacement of Alccofine, but a little decreasing trend after $20 \%$ replacement. Similarly, the 28days compressive strength of M30 grade concrete is varied from $39.25 \mathrm{~N} / \mathrm{mm}^{2}$ to $45.40 \mathrm{Mpa}$ up to $15 \%$ replacement of Alccofine, but a little decreasing trend after $20 \%$ replacement. The sevenday compressive strength of M40 grade concrete varies from $34.70 \mathrm{~N} / \mathrm{mm}^{2}$ to $40.62 \mathrm{Mpa}$ up to $15 \%$ replacement of Alccofine but a little decreasing trend after $20 \%$ replacement. Similarly, the 28days compressive strength of M40 grade concrete varies from $49.60 \mathrm{~N} / \mathrm{mm}^{2}$ to $57.65 \mathrm{Mpa}$ up to $15 \%$ replacement of Alccofine, but a little decreasing trend after $20 \%$ replacement

\subsection{Split tensile strength}

The split tensile strength of M20 grade increased from $4.80 \mathrm{~N} / \mathrm{mm} 2$, to $5.80 \mathrm{~N} / \mathrm{mm} 2$ up to $15 \%$ Alccofine replacement. The split tensile strength of M30 grade is increased from $5.10 \mathrm{~N} / \mathrm{mm} 2$, to 6.20 $\mathrm{N} / \mathrm{mm} 2$ up to $15 \%$ Alccofine replacement. The split tensile strength of M40 grade is varied from 5.2 $\mathrm{N} / \mathrm{mm} 2$, to $6.7 \mathrm{~N} / \mathrm{mm} 2$ up to $15 \%$ Alccofine replacement. The variations are made through Figures 10 to 12.

\subsection{Flexural strength}

The 28 days flexural tensile strength of M20 grade varied from $3.60 \mathrm{~N} / \mathrm{mm} 2$, to $4.0 \mathrm{~N} / \mathrm{mm} 2$ up to $15 \%$ Alccofine replacement. Similarly, this strength for M30 grade varied from $3.80 \mathrm{~N} / \mathrm{mm} 2$, to $4.20 \mathrm{~N} / \mathrm{mm} 2$. Finally, in M40 grade concrete it varied from 4.0 $\mathrm{N} / \mathrm{mm} 2$, to $4.50 \mathrm{~N} / \mathrm{mm} 2$ up to $15 \%$ Alccofine replacement and shown in Figures 13 to 15. 
BLN Sai Srinath et al.

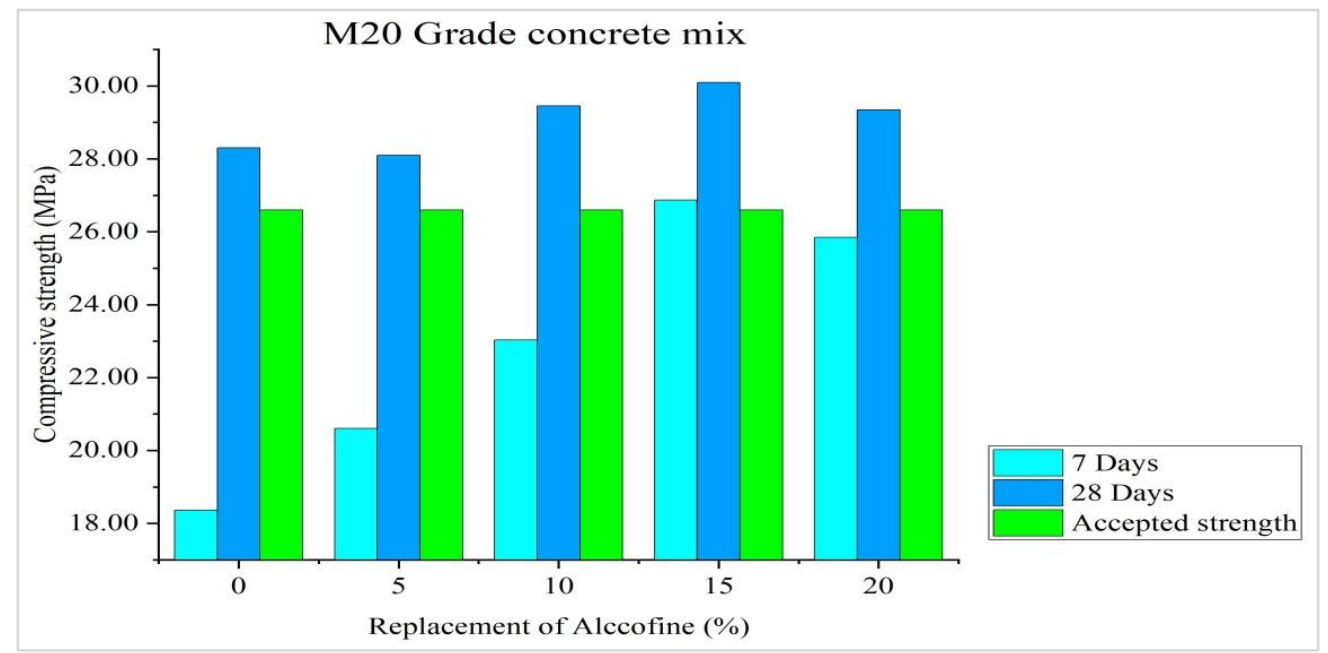

Figure 7 Compressive strength for M20 grade mix

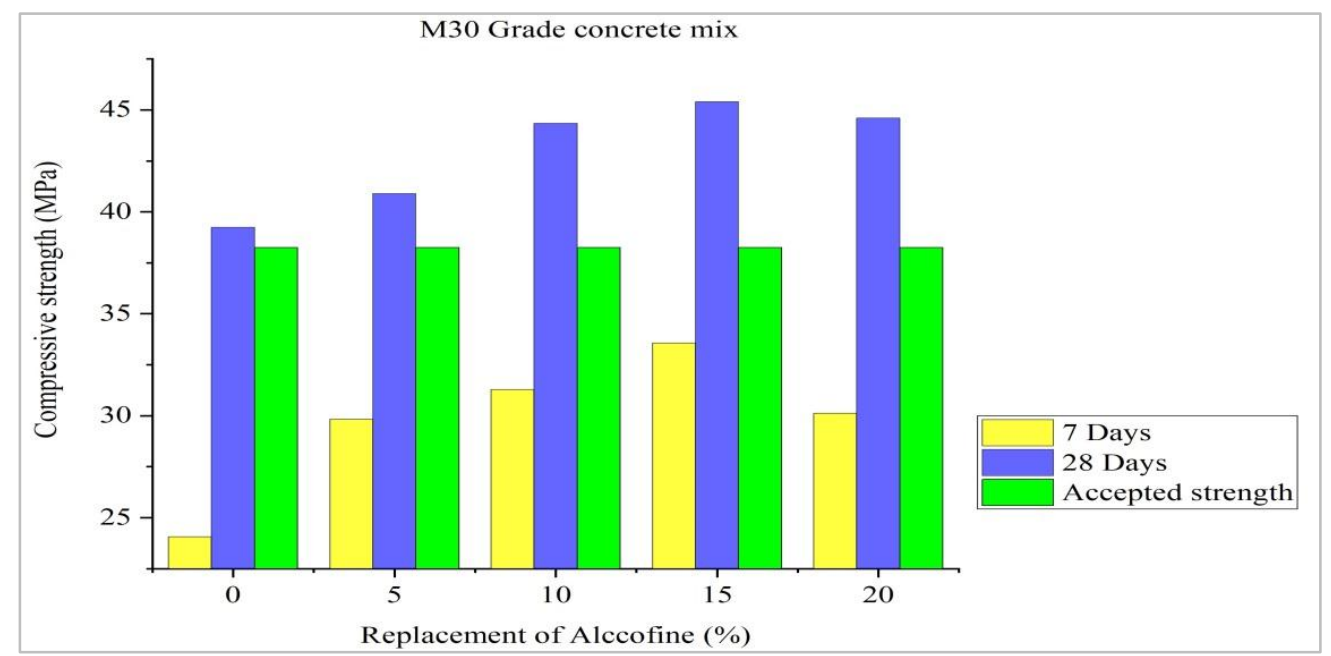

Figure 8 Compressive strength for M30 grade mix

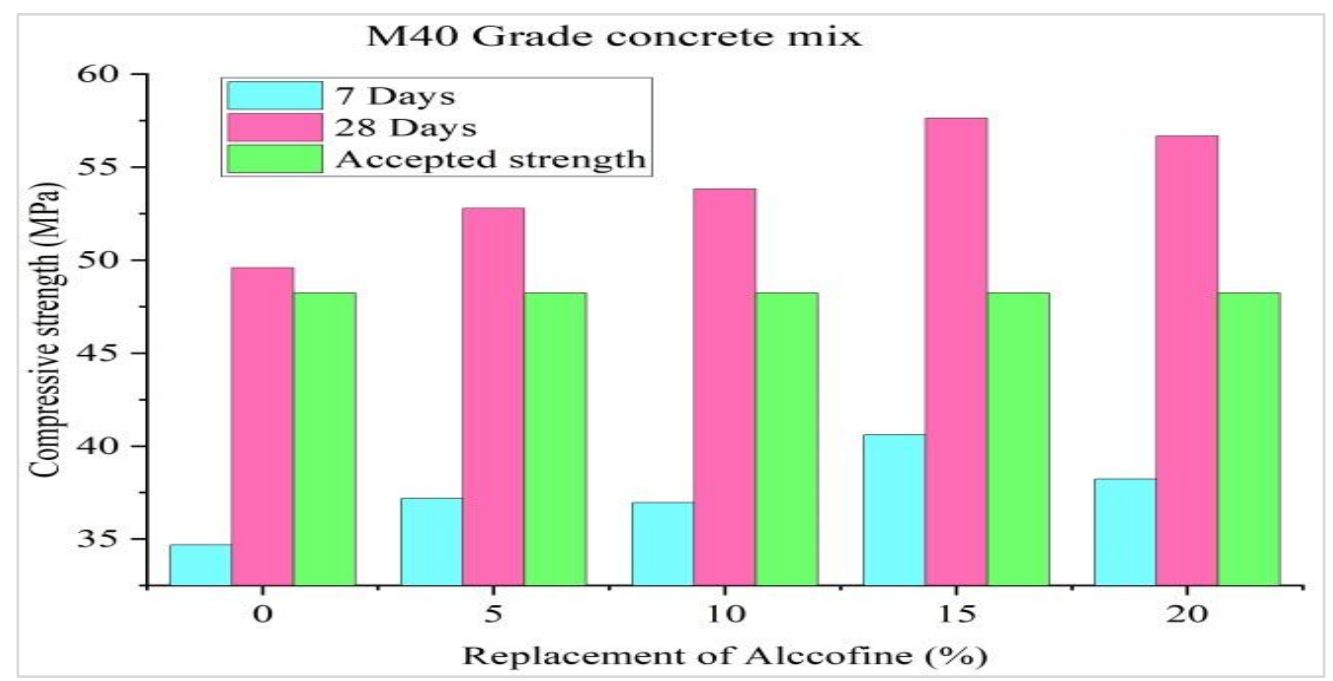

Figure 9 Compressive strength for M40 grade mix 


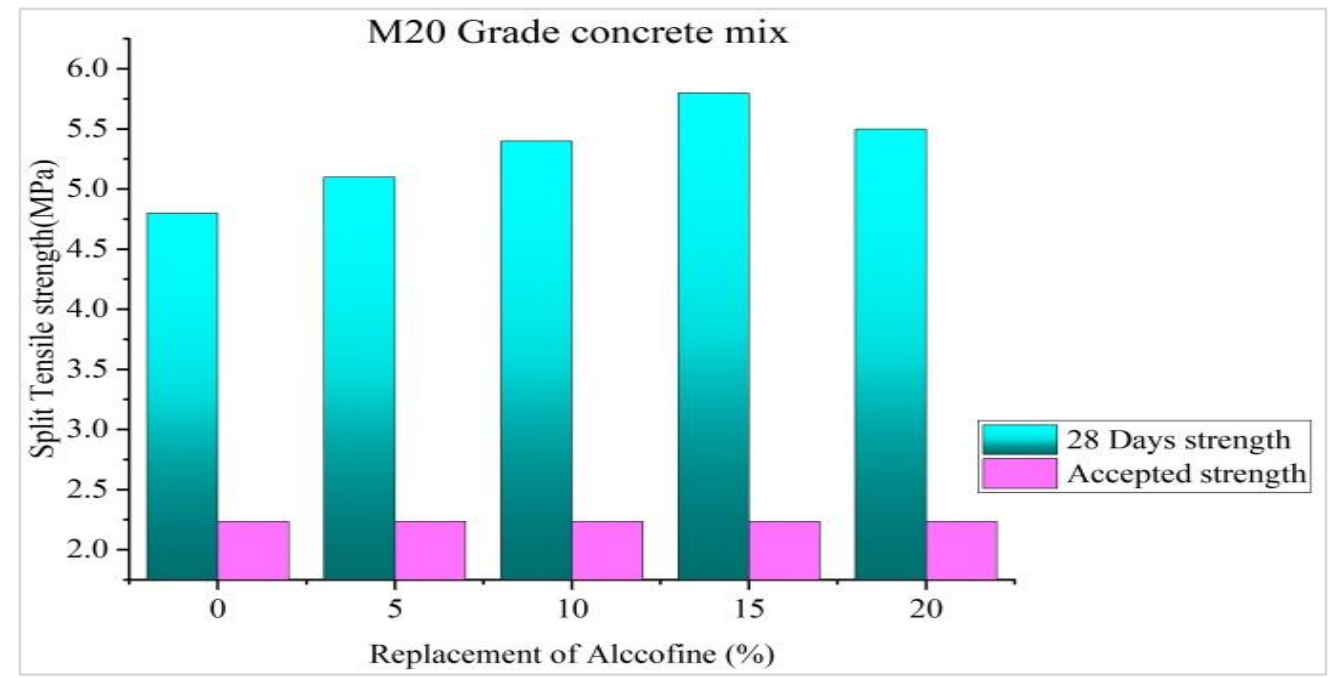

Figure 10 Split tensile strength for M20 grade mix

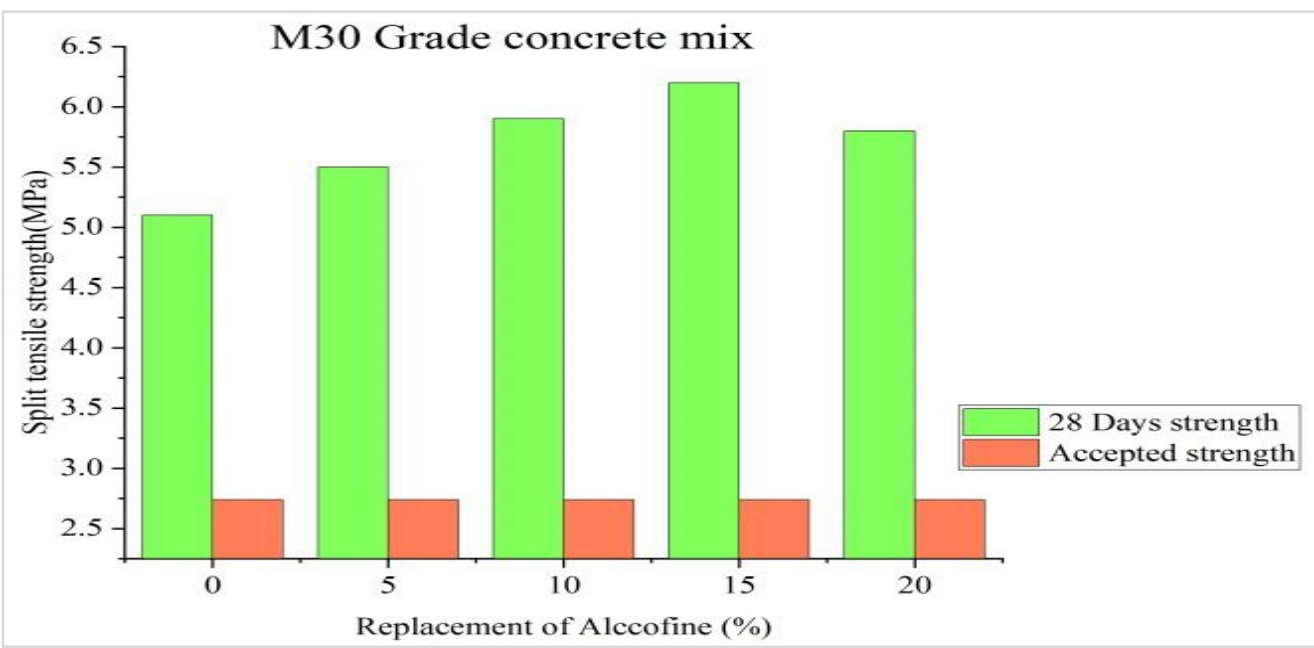

Figure 11 Split tensile strength for M30 grade mix

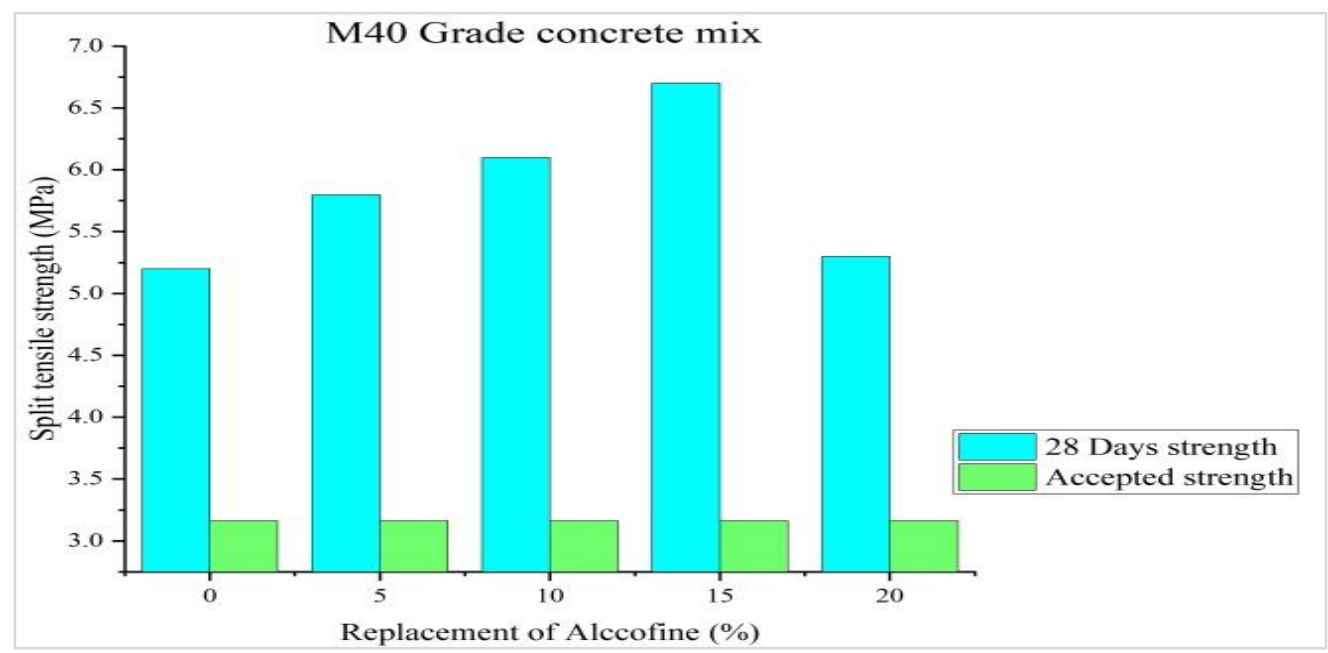

Figure 12 Split tensile strength of M 40 grade mix 
BLN Sai Srinath et al.

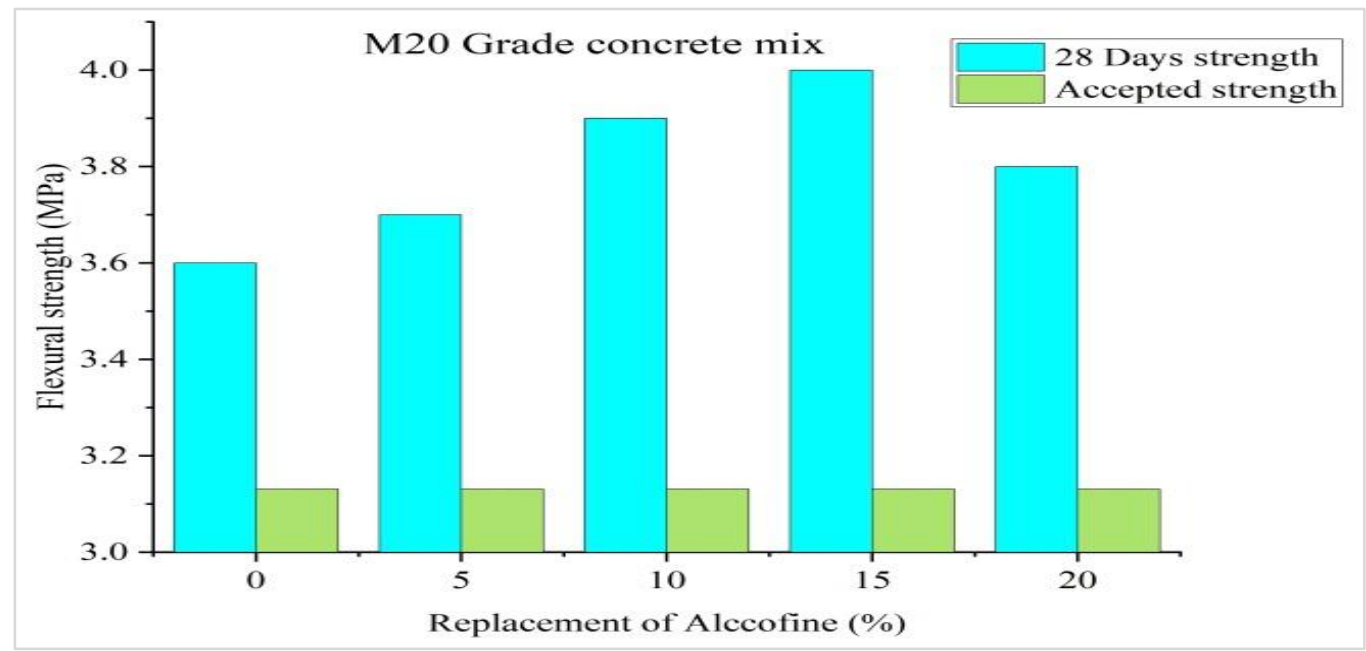

Figure 13 Flexural tensile strength for m20 grade mix

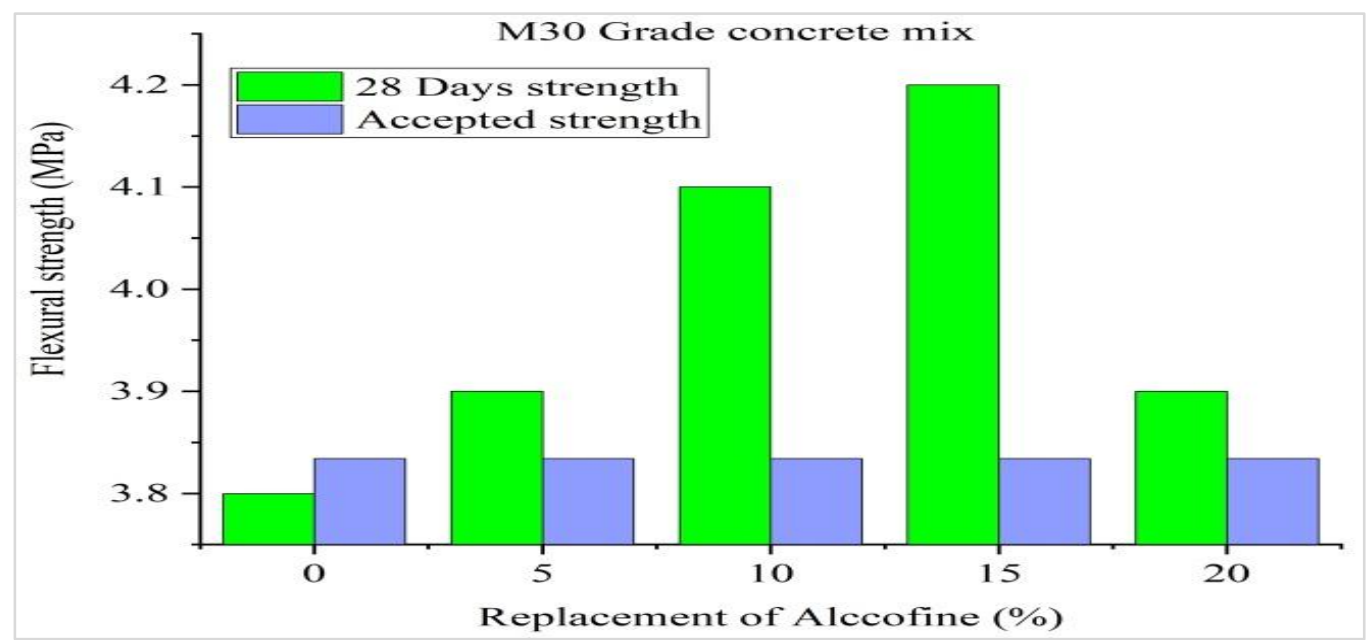

Figure 14 Flexural tensile strength for M30 grade mix

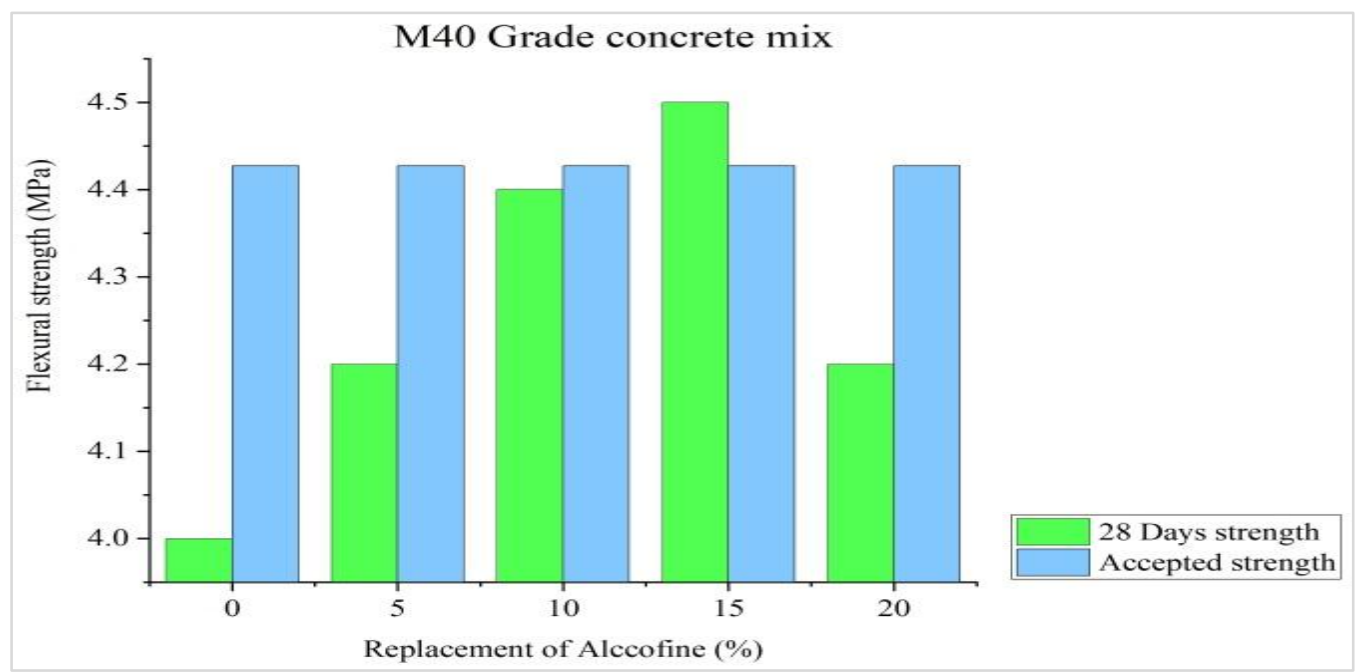

Figure 15 Flexural tensile strength for M40 grade mix 


\section{Discussions of the study}

In this part, the discussions of all the strengths viz., Compressive, tensile, and split tensile strengths of all the three grades are discussed as below from the above figures.

Compressive strength: generally considered as 28 days curing period, However, the early strength of the concrete is ascertained from the 7 days strength. It is generally $75 \%$ of the 28 days strength of the respective grade of the concrete. In the same procedure is adopted for the Alccofine concrete also. It is from Figure 7 the seven-day strength of the M20 grade is in the range of $18.37 \mathrm{~N} / \mathrm{mm}^{2}$ to 25.85 $\mathrm{N} / \mathrm{mm}^{2}$. However, the required strength is about $(75 / 100) \times 23=16.5 \mathrm{~N} / \mathrm{mm}^{2}$. All the mixes have shown higher results because of the fineness of the Alccofine material. But the increasing trend is slightly diminished between $15 \%$ and $20 \%$ of the Alccofine replacement in the mixes. Similarly, the required 28 days strength is $24 \mathrm{~N} / \mathrm{mm}^{2}$. However, the obtained strengths are $28.35 \mathrm{~N} / \mathrm{mm}^{2}$ to a maximum of $30.10 \mathrm{~N} / \mathrm{mm}^{2}$ at $15 \%$ Alccofine replacement. The change of trend is similar to the 7 days strength. Hence from the discussion, it is learnt that the strength gained from the 7 days to 28 days is very nominal in this M 20 grade concrete. In Figure 8 the strengths of the 7 days and the 28 days for the M30 grade is depicted. The trend from 7 days to 28 days is similar to M20 grade concrete, the strengths were also exhibited more than the required strength (i.e., $75 \%$ of 28 days strength). However, they have attained full strength at 28 days curing only. Similar to the above two figures the M40 grade concrete also exhibited a similar trend as shown in Figure 9. However, the rate of increase of strengths is a lesser rate when compared to the M20 and M30 grades of the concrete. However, the mixes have attained the required strengths for 7 days and 28 days curing period.

Split Tensile Strength: determined for ascertaining the tensile strength of Concrete, Though the concrete is very weak in tensile strength, the addition of Alccofine slightly increases the tensile strengths. For M 20, 30\& 40 grades of concrete, the required split strengths are $3.13,3.83$ and $4.43 \mathrm{~N} / \mathrm{mm}^{2}$ respectively. For M20 grade concrete, the split tensile strength was depicted in Figure 10. All mixes have higher strengths, and the maximum value was obtained at the $15 \%$ replacement of Alccofine. Similarly, the M30 and M 40 grades also have the corresponding trend which is shown in Figures 11 and 12.
Flexural Tensile Strength: In contrast to the split tensile strength the obtained flexural strengths have lower values. While calculating the results the experimental formula was used to find the strengths. The values are increasing from 0 to $15 \%$ alccofine replacement and decreasing to $20 \%$. A similar trend was obtained for the remaining M 30 and M40 grade mixes also. However, all the grades have similar trends also.

\subsection{Limitations of the study}

Alccofine is a totally new and manufactured material with silicon and lime in almost equal proportions. The suitability of Alccofine must be proved in several aspects to that of cement. The behaviour of Alccofine in concrete is yet to be studied for various parameters of concrete-like strength, durability, creep, shrinkage, flexure, permeability. Sufficient studies on the microstructure of Alccofine concrete are not available to explain the behaviour. Systematic operating procedures for mixing, testing and interpretation of results must be established. Indian Standard Code for this concrete has not yet been formulated. Adequate studies of properties like workability, water absorption etc., were found very scanty.

A complete list of abbreviations is shown in Appendix I.

\section{Conclusion and future work}

Even though the IS 10262-2019 code explicitly does not recommend the Alccofine as a partial replacement of cement in concrete mix proportions, the instructed guidelines are similar to other Supplementary cementitious materials viz., GGBS, FA is adopted in Alccofine replacement concrete mixes also. With the above procedure, the following conclusions have been drawn for asserting the suitability of the Alccofine in the concrete mixes. The 28 days compressive strength benchmark criteria satisfied the acceptance criteria laid down in IS 456200 code requirement.

The seven-day compressive strengths for all the three-grade concrete mixes have gained more than $70 \%$ of the 28 -day compressive strength. The 28 days strengths have also achieved the respective target mean strengths of M20, M30, and M40 grades. The split tensile strength is the direct tensile strength generally used for the deformation characteristics of concrete, but the closed-form solution was not recommended in IS 456-2000 code. Hence ACI 3812019 code formula was adopted. With this formula, 
$0.5 \sqrt{ } \mathrm{ft}$. All the concrete mixes were satisfied with the procedure. Similar to compressive strength, $15 \%$ replacement shows a higher value. The flexural strength of the $100 \times 100 \times 500 \mathrm{~mm}$ prisms was tested for all mixes with all percentages of replacements. The tested results were compared with the code recommended equation of IS456-2000. The tested values satisfied the code recommendations.

The 15\% Alccofine replacement concrete shows a higher value when compared to other replacements of Alccofine. 15\% replacement of Alccofine has shown the higher strengths in all the three-grades of concrete. More particularly, the 7-day compressive strength of M20 grade for $15 \%$ replacement of Alccofine achieved the 28 days strength. This $15 \%$ replacement was the optimum dosage of Alccofine replacement for the hydration process and strength gain satisfying the codal provisions. However, the partial replacements of 10 and $20 \%$ act as filler material in the bonding phase in the concrete. All the above results pertain to ordinary Portland cement with severe exposure conditions only.

- The optimum \% level of Alccofine can be considered to experiment on concrete subjected to elevated temperatures.

- Microstructural analysis can be carried for each grade of Alccofine concrete compared to nominal mix.

- Various durability and NDT tests can be conducted on various grades of Alccofine concrete compared to nominal concrete.

- Reinforced concrete beams and columns can be cast made of Alccofine concrete and can be studied for various strength characteristics.

\section{Acknowledgment}

None.

\section{Conflicts of interest}

The authors have no conflicts of interest to declare.

\section{Author contribution statement}

BLN Sai Srinath: Data collection, conceptualization, writing - original draft. Chandan Kumar Patnaikuni: overall review and supervision. Santhosh Kumar B: Investigation on challenges and draft manuscript preparation. Balaji K.V.G.D: Analysis and interpretation of results. Kode Venkata Ramesh: Data interpretation.

\section{References}

[1] Jindal BB, Singhal D, Sharma SK, Ashish DK. Improving compressive strength of low calcium fly ash geopolymer concrete with alccofine. Advances in Concrete Construction. 2017; 5(1):17-29.
[2] Vaidevi C, Kala TF, Kalaiyarrasi AR. Mechanical and durability properties of self-compacting concrete with marble fine aggregate. Materials Today: Proceedings. 2020; 22:829-35.

[3] Reddy PN, Naqash JA. Properties of concrete modified with ultra-fine slag. Karbala International Journal of Modern Science. 2019; 5(3):151-7.

[4] Rout MK, Biswas S, Sinha AK. Mechanical and durability properties of alccofine used in reclaimed asphalt concrete pavements (RACP). In advances in sustainable construction materials 2021 (pp. 131-42). Springer, Singapore.

[5] Reddy PN, Naqash JA. Development of high early strength in concrete incorporating alccofine and nonchloride accelerator. SN Applied Sciences. 2019; 1(7):1-11.

[6] Jindal BB, Singhal D, Sharma SK. Suitability of ambient-cured alccofine added low-calcium fly ashbased geopolymer concrete. Indian Journal of Science and Technology. 2017; 10(12).

[7] Reddy PN, Naqash JA. Strength prediction of high early strength concrete by artificial intelligence. International Journal of Engineering and Advanced Technology. 2019; 8(3):330-4.

[8] Kavyateja BV, Jawahar JG, Sashidhar C. Investigation on ternary blended self compacting concrete using fly ash and alccofine. International Journal of Recent Technology and Engineering. 2019; 7(6S):447-51.

[9] Siddique R, Kaur D. Properties of concrete containing ground granulated blast furnace slag (GGBFS) at elevated temperatures. Journal of Advanced Research. 2012; 3(1):45-51.

[10] Suthar SB, Shah BK. Study on strength development of high strength concrete containing alccofine and flyash. Indian Journal of Research. 2013; 2(3):102-4.

[11] Suthar S, Shah BK, Patel PJ. Study on effect of alccofine \& fly ash addition on the mechanical properties of high performance concrete. International Journal for Scientific Research \& Development. 2013; 1(3):464-7.

[12] Kumar R, Muthupriya P, Venkatsubramani R. The experimental investigating on durability characteristics of high performance concrete. The International Journal of Scientific and Technical Research. 2013; $3: 239-50$

[13] Soni D, Kulkarni S, Parekh V. Experimental study on high-performance concrete, with mixing of alccofine and flyash. Indian Journal of Research. 2013; 3(4):846.

[14] Prathyusha L, Naik BH. Effect of stone dust and fines on the properties of high strength self compacting concrete. International Journal of Civil Engineering and Technology. 2016; 7(6):393-9.

[15] Patil YO, Patil PN, Dwivedi AK. GGBS as partial replacement of OPC in cement concrete-an experimental study. International Journal of Scientific Research. 2013; 2(11):189-91.

[16] Pawar MS, Saoji AC. Effect of alccofine on self compacting concrete. International Journal of Engineering and Science. 2013; 2(6):5-9. 
[17] Swaroop AH, Venkateswararao K, Kodandaramarao P. Durability studies on concrete with fly ash \& GGBS. International Journal of Engineering Research and Applications. 2013; 3(4):285-9.

[18] Gayathri K, Ravichandran K, Saravanan J. Durability and cementing efficiency of alccofine in concretes. International Journal of Engineering Research \& Technology. 2016; 5(5):460-7.

[19] Sanjeev KLJ, Bhuvaneshwari P, Eswar M, Subramanian KA. Strength characteristics of alccofine based light weight concrete. International Journal of Civil Engineering and Technology. 2019; 10(3):136774.

[20] Reddy AN, Meena T. An experimental study to find the optimum dosage of admixtures in blended concrete. International Journal of Recent Technology and Engineering (IJRTE). 2019; 7(2):1062-5.

[21] Chandar SP, Gunasekaran K, Sandeep NS, Manikandaprabhu S. An experimental investigation on strength properties of steel fibres along with recycled aggregate in cement concrete. Rasayan Journal of Chemistry. 2017; 10(2):528-33.

[22] Agha MA, Sai PP, Vinay R, Goud AA. Development of early compressive strength in high performance concrete using perlite and alccofine. International Journal of Civil Engineering and Technology (IJCIET). 2018; 9(4):382-8.

[23] Kaviya B, Rohit K, Kindo S, Kumar JM, Divya P. Experimental study on partial replacement of cement using alccofine. International Journal of Pure and Applied Mathematics. 2017; 116(13):399-405.

[24] Ghising NL, Kumar V. Experimental investigation on properties of concrete with alccofine1203 as partial replacement of cement subjected to different curing regimes. International Journal of Mechanical and Production Engineering Research and Development. 2020; 10(3):4249-56.

[25] Rajesh KS, Samanta AK, Roy DK. An experimental study on the mechanical properties of alccofine based high grade concrete. International Journal of Multidisciplinary Research and Development. 2015; 2(10):218-24

[26] Narasimha RP, Ahmed NJ. Effect of alccofine on mechanical and durability index properties of green concrete. International Journal of Engineering. 2019; 32(6):813-9.

[27] Mathur M, Mathur A. Performance of concrete by partial replacement of alccofine-1203. International Journal of Engineering Research \& Technology. 2018; 6(11):1-5.

[28] Nainwal A, Chauhan A, Bhandari J. Comparison between simple concrete cubes and alccofine mixed concrete cubes (M20 Grade). International Journal of Scientific Research in Education. 2017; 5(9):6857-71.

[29] Gupta AK. Experimental study of strength relationship of concrete cube and concrete cylinder using ultrafine slag alccofine. International Journal of Science, Engineering and Research. 2014: 5(5) 102-7.

[30] Suganya R, Maheshwari L. Experimental investigation on alccofine concrete. International Journal of
Engineering Research \& Technology. 2019; 8(4):54850.

[31] Nishanth L, Patil NN. Experimental evaluation on workability and strength characteristics of selfconsolidating geopolymer concrete based on GGBFS, flyash and alccofine. Materials Today: Proceedings. 2021.

[32] Patil NN. Evaluation of strength, durability characteristics of flyash, GGBFS and alccofine based self-compacting geopolymer concrete. Materials Today: Proceedings. 2021.

[33] Harish B, Dakshinamurthy NR, Sridhar M, Rao KJ. A study on mechanical properties of high strength concrete with alccofine as partial replacement of cement. Materials Today: Proceedings. 2021.

[34] IS 10262. Concrete mix proportioning-guidelines. Bureau of Indian Standards. 2009.

[35] https://www.iitk.ac.in/ce/test/IScodes/is.2386.1.1963.pdf. Accessed 25 July 2021.

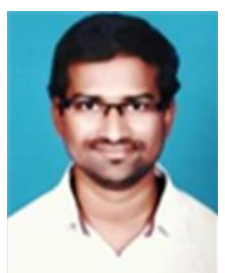

BLN Sai Srinath is currently pursuing a $\mathrm{PhD}$ in Structural Engineering from G.I.T.A.M. University, Visakhapatnam, and Andhra Pradesh, India. He completed his M.Tech in Structural Engineering \& Natural Disaster Management from G.I.T.A.M. University, Visakhapatnam, and Andhra Pradesh, India. She has published journals in indexed journals.

Email: srinath296@gmail.com

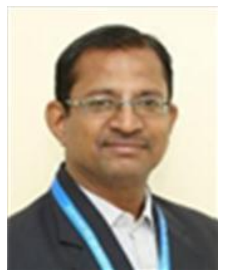

Dr. Chandan Kumar Patnaikuni is currently serving as an Assistant Professor in Civil Engineering Department in G.I.T.A.M. University, Visakhapatnam, and Andhra Pradesh, India. He has published more than 60 Research papers in National and International journals. He is a member of Indian Concrete Institute and Institute of Engineers (India)

Email: pckumar27@gmail.com

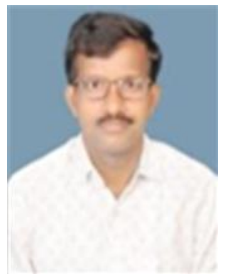

Dr Santhosh Kumar B. is serving a Deputy Executive Engineer in the Water Resources Department, Vizianagaram. He Completed A.M.I.E. (Civil), M.Tech (Strut) and $\mathrm{PhD}$ in Structural Engineering. He has 17 years of experience in the Water Resources sector. His areas of interest are Wind Engineering, Structural Dynamics, and Reinforced Concrete structures. He has published more than 19 Research papers in various journals and Conferences. He is a Member of the Institution of Engineers (I), Indian Geotechnical Society. International Association of Engineers.

Email: santhoshamie@gmail.com 


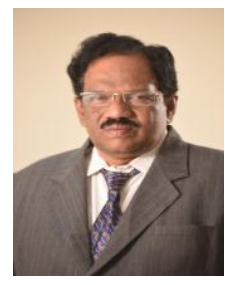

Prof. Balaji K.V.G.D, $\mathrm{PhD}$ is a Distinguished Professor in the civil engineering department with 30 years of teaching experience. He is a member of various prestigious societies and professional bodies like I.S.T.E., I.S.C.M.S., I.S.R.M.T.T., I.R.C., I.N.S.D.A.G., I.S.R.S., I.S.E.T., I.G.S., C.M.S.I., F.I.E., FIV, F.I.P.H.E. Presently working as a Professor in the Department of Civil Engineering, G.I.T.A.M. University, and Visakhapatnam. $\mathrm{He}$ is a Licensed Structural Engineer of V.U.D.A. \& G.V.M.C. Member (C.E.D. 57) and a member of the Bureau of Indian Standards. His yeoman services as a lecturer, professor, and Head of Department enriched the knowledge of thousands of students. He is a stalwart of structural analysis and has nearly $11 \mathrm{PhDs}$ in progress at present in addition to $3 \mathrm{PhDs}$ completed. More than 80 papers were published in various esteemed reputable National and International Journals.

Email: balajigitam@gmail.com

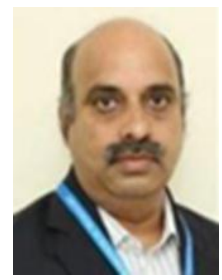

Dr Kode Venkata Ramesh, $\mathrm{PhD}$ is currently working as a Professor in the department of civil engineering, G.I.T.A.M. Institute of Technology, Visakhapatnam Campus, Visakhapatnam. He has published several publications in National and International Journals. His areas of interest are in Sustainable Concrete subjected to Elevated Temperatures and Health Monitoring of Structures.

Email: rkode@gitam.edu

\begin{tabular}{|c|c|c|}
\hline S. No. & Abbreviations & Description \\
\hline 1 & $\mathrm{Al}$ & Alccofine \\
\hline 2 & $\mathrm{Al}_{2} \mathrm{O}_{3}$ & Aluminium Oxide \\
\hline 3 & $\mathrm{Cao}$ & Calcium Oxide \\
\hline 4 & C.A. & Coarse Aggregate \\
\hline 5 & $\mathrm{CO}_{2}$ & Carbon-di-Oxide \\
\hline 6 & CTM & Compression Testing Machine \\
\hline 7 & FA & Fly Ash \\
\hline 8 & $\mathrm{Fe}_{2} \mathrm{O}_{3}$ & Ferric Oxide \\
\hline 9 & GGBS & Ground Granulated Blast Slag \\
\hline 10 & GHG & Green House Gases \\
\hline 11 & HSC & High Strength Concrete \\
\hline 12 & M20 & M20 Grade Concrete Mix \\
\hline 13 & M30 & M30 Grade Concrete Mix \\
\hline 14 & M35 & M35 Grade Concrete Mix \\
\hline 15 & M40 & M40 Grade Concrete Mix \\
\hline 16 & M50 & M50 Grade Concrete Mix \\
\hline 17 & $\mathrm{MgO}$ & Magnesium Oxide \\
\hline 18 & MSA & Maximum Size of Aggregate \\
\hline 19 & NDT & Non Destructive Tests \\
\hline 20 & SCGC & $\begin{array}{ll}\text { Self-Consolidating } & \text { Geopolymer } \\
\text { Concrete } & \end{array}$ \\
\hline 21 & $\mathrm{SCM}$ & $\begin{array}{l}\text { Supplementary } \\
\text { Materials }\end{array}$ \\
\hline 22 & $\mathrm{SiO}_{2}$ & Silicon Dioxide \\
\hline 23 & $\mathrm{SO}_{3}$ & Sulphur Trioxide \\
\hline 24 & S.P & Super Plasticizer \\
\hline 25 & $\mathrm{pH}$ & Potential of Hydrogen \\
\hline 26 & UTM & Universal Testing Machine \\
\hline 27 & IS 2389 & \\
\hline 28 & IS 10262 & \\
\hline 29 & IS 456 & Indian Standard Codes \\
\hline 30 & IS 516 & \\
\hline
\end{tabular}

